\title{
HEMATOLOGICAL ANALYSIS OF Micropogonias furnieri, DESMAREST, 1823, SCIANIDAE, FROM TWO ESTUARIES OF BAIXADA SANTISTA, SÃO PAULO, BRAZIL*
}

Robson Seriani $^{1} * *$, Lucas Buruaem Moreira ${ }^{1,2}$, Denis Moledo de Souza Abessa ${ }^{1}$, Laís D. Abujamara ${ }^{3}$, Natashy S. B. de Carvalho ${ }^{1}$, Luciane Alves Maranho ${ }^{1}$, Aline A. Kirschbaum ${ }^{4}$ and Maria José T. Ranzani-Paiva ${ }^{5}$

${ }^{1}$ Universidade Estadual Paulista Júlio de Mesquita Filho - UNESP

Campus Experimental do Litoral Paulista

(Praça Infante Dom Henrique, s/n, 11330-900 São Vicente, SP, Brasil)

${ }^{2}$ Universidade Federal do Ceará

Instituto de Ciências do Mar (LABOMAR)

(Av. Abolição, 3207, 60165-081 Fortaleza, CE, Brasil)

${ }^{3}$ Universidade Santa Cecília

(Rua Oswaldo Cruz, 277, 11045-907 Santos, SP, Brasil)

${ }^{4}$ Universidade de São Paulo

Instituto Oceanográfico

(Praça do Oceanográfico, 191, 05508-120 São Paulo, SP, Brasil)

${ }^{5}$ Instituto de Pesca-SP - IP/SAA-APTA.

Laboratório de Patologia de Organismos Aquáticos

(Av, Francisco Matarazzo, 455, 05001-000 São Paulo, SP, Brasil)

**Corresponding author: robsonseriani@yahoo.com.br

\section{A B S T R A C T}

Hematological alterations in fish are considered a useful tool to evaluate pathological processes resulting from the exposure to environmental pollutants. The whitemouth croaker Micropogonias furnieri is a common species in estuarine areas and potentially exposed to many contaminants. In the present study, the hematological characteristics of fish collected at two sites in Baixada Santista (Santos Estuarine System - SES, a polluted site; and the Estuary of Itanhaém River - EIR, unpolluted site) del was analysed. The following blood descriptors were analyzed: number of Erythrocytes (Er), Hematocrit (Ht), Hemoglobin (Hb), Mean Corpuscular Volume (MCV) and Mean Corpuscular Hemoglobin concentration (MCHC). Fish from SES exhibited significant lower levels of $\mathrm{Ht}$ and increase on $\mathrm{MCHC}$ and $\mathrm{Hb}$. Such differences are likely related to the different contamination levels found in these estuaries.

\section{RESUMO}

Alterações hematológicas em peixes são consideradas uma importante ferramenta para avaliar processos patológicos decorrentes da exposição a poluentes ambientais. Micropogonias furnieri (Desmarest, 1823) (corvina) é comumente encontrada em regiões estuarinas e eventualmente está exposta a inúmeros contaminantes. No presente estudo foi avaliado o quadro hematológico de indivíduos de M. furnieri coletados na Baixada Santista: o Sistema Estuarino de Santos, considerado poluído, e o estuário do Rio Itanhaém (controle). Foram avaliados o número de Eritrócitos (Er), o Hematócrito (Ht), a taxa de Hemoglobina (Hb), o Volume Corpuscular Médio (VCM) e a Concentração de Hemoglobina Corpuscular Média (CHCM). Nos peixes coletados no Sistema Estuarino de Santos, os níveis de Ht foram significativamente menores, enquanto os níveis de CHCM e $\mathrm{Hb}$ foram significativamente mais altos, indicando que os prováveis efeitos estejam atribuídos aos diferentes níveis de contaminação encontrados nos estuários.

Descriptors: M. furnieri, Hematology, Pollution, Estuaries, Itanhaém, Santos. Descritores: M. furnieri, Hematologia, Poluição, Estuários, Itanhaém, Santos. 


\section{INTRODUCTION}

The contaminants released into aquatic ecosystems may become available to the biota and produce metabolic changes in the exposed organisms, such as neurotoxicity, infertility, immunological disorders, endocrine disruption, development and reproduction inhibition, genetic disorders, susceptibility to diseases, among other effects that can lead to death (STEGEMAN et al., 1992).

Such effects may be transferred to the higher levels of biological organization, producing effects on the population, community and even ecosystem level, and threatening the food chain of the oceans. In addition, many pollutants are persistent in the environment, bioaccumulating in aquatic organisms and becoming potentially transferable through the food chain, which ultimately may represent a risk to human health by the ingestion of contaminated organisms.

The International Council for Exploration of the Sea (ICES) recommends that marine environmental monitoring programs should employ biomarkers as a complementary technique to address the toxicity of contaminants to organisms (BURGEOT et al., 1996), especially as early warning tools which allow the detection of effects before the occurrence of irreversible damage (DE CAPRIO, 1997).

There are many different biomarkers available for use in environmental studies, such as biochemical (PEREIRA et al., 2007), physiological (DEPLEDGE; ANDERSEN, 1990), cito-genotoxical (KIRSCHBAUM, et al., 2009), histological (PACHECO; SANTOS, 2002), among others. The analysis of fish blood is an easy approach which provides information on the physiological conditions of animals exposed to contaminants, and may be used to evaluate the responses of fish exposed to pollutants (OLIVEIRA-RIBEIRO et al., 2000; ADHIKARI et al., 2004; SHAH, 2006; FRANÇA et al., 2007). However, the literature on the hematology of marine and estuarine species is still scarce.

According to Ranzani-Paiva and Silva-Souza (2004), only about fourteen Brazilian marine teleosts have known hematological characteristics; thus there is an urgent necessity of studies to describe the normal standards for the blood of healthy fish, as well as to understand how the blood responds to environmental contamination.

Micropogonias furnieri, Desmarest, 1823 (Scianidae) is an economically and ecologically important species, which feeds on the bottom and represents a source of food for the local fishermen. Its diet is diverse and composed mainly by small fish and benthic organisms. Thus this species appears to be in close contact with sediments, being affected by changes in the sediment quality. Its geographic distribution is broad, extending from the Gulf of
Mexico to the Gulf of San Matias, in Argentina (CARNEIRO et al., 2005). In São Paulo, M. furnieri is commonly found along the coast, in shallow waters and within the estuaries (CARNEIRO et al., 2005), constituting an important natural resource, not only for traditional fishermen but also for industrial fisheries. However, since many coastal areas of the state are increasingly becoming contaminated (LAMPARELLI et al., 2001), this species may be subject to the harmful effects of pollution.

In this context, this study aimed to characterize the erythrocytic variables of $M$. furnieri collected at two estuaries of São Paulo, the Santos Estuarine System (SES - a polluted area) and the Estuary of Itanhaém River (EIR - unpolluted area Control) (ABESSA et al., 2006; SERIANI, et al., 2006; 2008).

\section{Materials AND Methods}

The estuary of Itanhaém River is located by Itanhaém city, in the south of Baixada Santista Metropolitan Region, central coast of São Paulo $\left(23^{\circ} 50^{\prime}-24^{\circ} 15^{\prime} \mathrm{S}, 46^{\circ} 35^{\prime} 00^{\prime \prime} \mathrm{W}\right)$. The surrounding area is characterized by an important commercial fishing activity. According to CETESB (2008) water quality in this region has good quality throughout the year. Moreover, its basin presents a high percentage of natural vegetation, specially mangroves and Atlantic Forest, being partially protected by federal legislation and also as a formal State Protected Area and State Park. Previous studies report that waters and sediments from the Estuary of Itanhaém River exhibit good quality (ABESSA et al., 2006; CAMARGO; BIÚDES, 2006; BIÚDES; CAMARGO, 2006; SERIANI et al., 2006; 2008).

On the other hand, the Santos Estuarine System $\left(23^{\circ} 30^{\prime}-24^{\circ} \mathrm{S}, 46^{\circ} 05^{\prime}-46^{\circ} 30^{\prime} \mathrm{W}\right)$ is characterized as a highly polluted area, where multiple contamination sources are present, such as the industrial complex of Cubatão, the Port of Santos, the discharge of untreated sewage by non-point sources and outfalls, the input of urban drainage waters, irregular industrial landfills, domestic landfills, among others. In this context, the local ecosystems and biota are under risk, in particular those related to the unconsolidated substratum, since the sediments are toxic and contaminated by metals, poly-aromatic hydrocarbons (PAHs), poly-chlorinated biphenyls (PCBs), detergents and other substances (CESAR et al., 2007; SOUSA et al., 2007; LAMPARELLI et al., 2001; MEDEIROS; BÍCEGO, 2004; HORTELLANI et al., 2005; ABESSA et al., 2008). However, despite such authors have showed that the contamination of SES sediments can affect the water column organisms, the actual effects still are unknown and need to be evaluated. 
Young individuals of $M$. furnieri were collected at $\operatorname{EIR}(\mathrm{n}=13)$ and $\operatorname{SES}(\mathrm{n}=11)$ and immediately transferred to tanks containing water from the collection site. After their transportation to the laboratory, fish were anesthetized with benzocaine (3\%), measured and weighed, and blood samples were taken from the caudal vein with a heparinized syringe. Such blood samples were used for the red blood cell (RBC) determinations by: dilution with Natt and Herrick (1952) solution and counting in a Neubauer chamber; hematocrit $(\mathrm{Ht})$ by the microhematocrit technique (Goldenfarb et al., (1971); hemoglobin level $(\mathrm{Hb})$ by the cyanomethemoglobin method (Collier, 1944); and mean corpuscular volume (MCV) and mean corpuscular hemoglobin concentration (MCHC), according to Wintrobe (1934). After the blood was sampled the animals were sacrificed by deep sedation and the gonads were removed for sex determination. Results were submitted to t-student test and considered significant when $\mathrm{p}<0.05$ (ZAR, 1996).

\section{Results}

Among the thirteen specimens caught in EIR, 8 were females and 5 were males. The females exhibited mean length of $15.5 \pm 7.8 \mathrm{~cm}$ and mean weight of $35.3 \pm 5.6 \mathrm{~g}$, whereas males had mean length of $15.9 \pm 11.6 \mathrm{~cm}$ and weight of $39.5 \pm 7.5 \mathrm{~g}$. In SES, 8 females and 3 males were obtained, with respective mean lengths of $25.9 \pm 16 \mathrm{~cm}$ and $21.8 \pm$ $19.1 \mathrm{~cm}$, and mean weights of $30.8 \pm 12.5 \mathrm{~g}$ and 100.7 $\pm 31.1 \mathrm{~g}$. There were no statistical differences between the erythrocytic variables of males and females. However, when fish from the two sites were compared (Table 1), significant differences were observed for $\mathrm{Ht}$ (p <0.01), Hb (p <0.002) and MCHC ( $<<0.0001)$.

Table 1. Erythrocytic variables of $M$. furnieri collected at EIR and SES $(*=p<0.01 ; * *=p<0.0002$ and $* * *=p<0.0001)$. Ht, $\mathrm{Hb}$ and $\mathrm{MCHC}$ were different in fish from SES.

\begin{tabular}{ccc}
\hline \hline $\begin{array}{c}\text { Erythrocytic } \\
\text { variables }\end{array}$ & $\begin{array}{c}\text { Estuary of } \\
\text { Itanhaém River } \\
(\mathbf{n = 1 3})\end{array}$ & $\begin{array}{c}\text { Santos } \\
\text { Estuarine } \\
\text { System }(\mathbf{n}=\mathbf{1 1})\end{array}$ \\
\hline Ht $(\boldsymbol{\%})$ & $32.6 \pm 3.8$ & $\mathbf{2 9 . 1} \pm \mathbf{2 . 3} *$ \\
$\mathbf{E r}(\mathbf{1 0} / \boldsymbol{\mu L})$ & $339.0 \pm 124.4$ & $285.2 \pm 64.3$ \\
$\mathbf{H b}(\mathbf{g} / \mathbf{d L})$ & $7.4 \pm 0.3$ & $\mathbf{8 . 1} \pm \mathbf{0 . 2} * *$ \\
$\mathbf{M C V}(\boldsymbol{\mu 3})$ & $113.0 \pm 51.7$ & $110.73 \pm 47.6$ \\
$\mathbf{M C H C}(\boldsymbol{\%})$ & $22.9 \pm 2.5$ & $\mathbf{2 7 . 6} \pm \mathbf{2 . 0 3} * * *$ \\
\hline
\end{tabular}

\section{DisCUSSSION}

The analysis of the erythrocytic variables is focused in the evaluation of the anemia induction processes, which are frequently associated to a bad nutrition status or to contaminants exposure. Fish exposed to metals, pesticides and effluents exhibit hematological changes, not only after laboratory exposure, but also when the exposure occurs in the field (RANZANI-PAIVA et al., 1997; OLIVEIRARIBEIRO et al., 2006; ADHIKARI, 2004; SHAH, 2006; FRANÇA et al., 2007). Other authors reported that such responses may vary according to the gender, as observed for Salminus maxilosus (RANZANIPAIVA et al., 2003). However, in the present study, for both estuaries, sexually immature males and females exhibited similar blood characteristics. A similar result was observed in sexually immature Mugil platanus from Cananéia Estuary by RanzaniPaiva (1995).

Some blood parameters, however, showed differences between the polluted and the unpolluted sites. Individuals from SES exhibited higher mean $\mathrm{Hb}$ and MCHC and lower $\mathrm{Ht}$, when compared to the EIR fish. Rao et al. (1990) observed that in the port of Bay of Bengal, India, where the concentrations of heavy metals and hydrocarbons were high, fish showed deep changes in the erythrocytic variables, presenting anemia, which was related to the synergism of many pollutants to which the animals were exposed. França et al. (2007) found that pollutants such as $\mathrm{Hg}+\mathrm{Se}^{6}$ induced significant changes in the erythrocyte set, suggesting that such effects depend on the oxidation levels of the chemical elements.

In the case of EIR, an environment with low degradation, if any, the lower MCHC values and the higher number of erythrocytes may be related to the maintenance of a higher erythropoiesis rate, which could be observed through the RBC and Ht values (Table 1). In fact, under estuarine conditions, in which salinities and temperatures are very variable and the dissolved oxygen in waters and sediments is generally low, the continuous and enhanced production of red blood cells may be expected. However, in the case of SES and EIR, the circulation conditions are intense and maintain the dissolved oxygen (D.O) levels close to saturation (ABESSA et al., 2006; 2008; HARARI et al., 2008). Moreover, as both are shallow estuaries, they do experience similar temperature variations, from approximately $20^{\circ} \mathrm{C}$ or less in the winter to more than $26^{\circ} \mathrm{C}$ in the summer (ABESSA et al., 2008; HARARI et al., 2008; CAMARGO; BIÚDES, 2006; BIÚDES; CAMARGO, 2006; SERIANI et al., 2006, 2008). Regarding the salinities, a similar situation occurs, since SES and EIR show salinity values ranging from $2 \pm 2 \%$ o during summer low tides to 35 $\pm 2 \%$ at winter high tides (ABESSA et al., 2008; 
HARARI et al., 2008; SERIANI et al., 2006, 2008). Thus, once the basic physical-chemical conditions of both estuaries range in a relatively comparable mode, it may be assumed that such variables have a similar influence on fish from both sites. Thus, these natural environmental variables were probably not the cause of differences observed in the blood parameters.

The results observed for the SES organisms indicated strong evidences of erythropoiesis inhibition, characterized by the high concentration of $\mathrm{Hb}$ in erythrocytes and high MCHC, and a lower number of erythrocytes. Older blood tends to present less erythtocytes but higher concentrations of $\mathrm{Hb}$ and MCHC, which is possibly a strategy to optimize the oxygen absorption, when the erythropoiesis is inhibited and the environmental conditions are not favorable, whether it is due to natural factors (such as natural hypoxia or estuarine eutrophication) or to the presence of contaminants.

According to Tetens and Christensen (1987), hormones, such as catecholamines, are released during stress periods, including those caused by pollutants exposure. Such hormones induce changes in the blood cells balance, and can stimulate the increase in the $\mathrm{MCV}$ or in MCHC. Such changes in MCHC were probably triggered by stress in the aerobic metabolism. In this sense, the organisms did not react producing erythroblasts/erythrocytes because erythropoiesis was inhibited, as indicated by the significant changes in $\mathrm{Ht}$.

Moreover, the influence of catecholamines on the MCHC increase may be also related to their action on the cells metabolism: these hormones cause increase in the permeability of erythrocyte membranes and in the hemoglobin affinity to oxygen (TETENS; CHRISTENSEN, 1987). The catecholamines produced during stress lead to increases in cell volume due to retention of sodium and chloride in the cytosol, increasing the osmolarity and consequently the volume of the erythrocytes (NIKINMAA; HUESTIS, 1984; NIKINMAA, 1982; RAILO et al., 1985).

An alternative hypothesis, in which the erythrocytes have suffered haemolysis (SHAH, 2006, ADHIKARI et al., 2004, FRANÇA et al., 2007), can be discarded, since the SES fish exhibited high levels of MCHC and $\mathrm{Hb}$. Only the reduction of Er does not necessarily indicate hemolysis because, in this case, there is also a reduction of $\mathrm{Hb}$ by leaching, reducing its erythrocyte concentration (MCHC).

The differences observed in some blood characteristics of $M$. furnieri from EIR and SES were possibly associated to responses to environmental contaminants. Thus, there are evidences that the aquatic biota is under stress in SES, due to pollution; however our results cannot perfectly separate the effects induced by the natural and by anthropic factors, showing the need for more studies dedicated to the understanding of the role of each factor on the fish responses.

\section{ACKNOWLEDGEMENTS}

To Silvia Vicente for the manuscript review and suggestions to this investigation, to the anonymous reviewers, whose suggestions improved the article, to Dr Marion Nipper (Texas A\&M University), who kindly reviewed the final version of the manuscript, and to the local fishermen, specifically Mr. Ricardo, Mr. Yu and Mr. José Aparecido de Jesus, who helped us to collect M. furnieri at EIR and SES.

\section{REFERENCES}

ABESSA, D. M. S. ; PINNA, F. V. ; ROMANO, P. ; SERIANI, R. ; SILVEIRA, F. L.; MAGINI, C. Water quality at the Estuary of the Itanhaém River, SP, Brazil. In: ENVIRONMENTAL AND HEALTH WORLD CONGRESS, 2006, Santos, SP. Proceedings ... Santos, SP: COPEC, 2006. p. 42-45.

ABESSA, D. M. S.; CARR, R. S.; SOUSA, E. C. P. M.; RACHID, B. R. F.; ZARONI, L. P.; PINTO, Y. A.; GASPARRO, M. R.; BÍCEGO, M. C.; HORTELLANI, M. A.; SARKIS, J. E.; MACIEL, P. M. Integrative ecotoxicological assessment of a complex tropical Estuarine System. In: HOFFER, T. N. (Org.). Marine Pollution: New Research. New York: Nova Science Publishers, 2008. p. 1-36.

ADHIKARI, S.; SARKAR, B.; CHATTERJEE, A.; MAHAPATRA, C. T.; AYYAPPAN, S. Effects of cypermethrin and carbofuran on certain hematological parameters and prediction of their recovery in a freshwater teleost; Labeo rohita (Hamilton). Ecotoxicol. Environ. Saf., v. 58, p. 20-226, 2004.

BIUDES, J. F. V.; CAMARGO, A. F. M. Changes in biomass, chemical composition and nutritive value of Spartina alterniflora due to organic pollution in the Itanhaém River Basin (SP, Brazil). Braz. J. Biol., v. 66, n. 3, p. 781-789, 2006.

BURGEOT, T.; BOCQUÉNÉ, G.; PORTE, C.; DIMMET, J.; SANTELLA, R. M.; GARCIA DE LA PARRA, L. M., PFTOL-LESZKOWICZ, A., RAOUX, C.; GALGANI, F. Bioindicators of pollutant exposure in the nothwestern Mediterranean Sea. Mar. Ecol. Prog. Ser., v. 131, p. 125-141, 1996.

CAMARGO, A. F. M.; BIUDES, J. F. V. Influence of limnological characteristics of water in the occurrence of Salvinia molesta and Pistia stratiotes in rivers from the Itanhaém River basin (SP, Brazil). Acta limnol. Bras., v. 18, n. 3, p. 239-246, 2006.

CARNEIRO, M. H.; CASTRO, P. M. G. DE; TUTUI, S. L. DOS S.; BASTOS, G. C. C. Micropogonias furnieri (Desmarest, 1823) (Estoque Sudeste) IN: ROSSIWONGTSCHOWSKI, C. L. D. B. (Org.). Análise das principais pescarias comerciais do sudeste-sul do Brasil: Dinâmica populacional das espécies em explotação. São Paulo: Programa REVIZEE/MMA/SECIRM/FEMAR., 2005. p. 94-100. 
CESAR, A.; CHOUERI, R. B.; RIBA, I.; MORALESCASELLES, C.; PEREIRA, C.D.S.; SANTOS, A. R.; ABESSA, D. M. S.; DELVALLS, T. A. Comparative sediment quality assessment in different littoral ecosystems from Spain (Gulf of Cadiz) and Brazi (Santos and São Vicente Estuarine System). Environment int., v. 33, p. 429-435, 2007.

COLLIER, H. B. The standardization of blood haemoglobin determinations. Can. med. Assoc. J., v. 50, p. 550-552, 1944.

CETESB - Companhia de Tecnologia de Saneamento Ambiental. Relatório de qualidade das águas litorâneas do Estado de São Paulo. São Paulo, 2007.

DE CAPRIO, A. P. Biomarkers: coming age for Environmental health and risk assessment. Critical review. Environ. Sci. Technol., v. 31, p. 1837-1848, 1997.

DEPLEDGE, M.; ANDERSEN, A. A computer-aided physiological monitoring system for continuous, longterm recording of cardiac activity in selected invertebrates. Comp. Biochem. Physiol., v. 96, p. 473477, 1990.

FRANÇA, J. K. G; RANZANI-PAIVA, M. J. T.; LOMBARDI, J. V.; CARVALHO, S.; SERIANI, R. 2007. Toxicidade crônica do cloreto de mercurio associado ao selenio por meio do estudo hematológico em tilápia Oreochromis niloticus. Bioikos, v. 21, n. 1, p. 11-19., 2007.

GOLDENFARB, P. B.; BOWYER, F. P.; HALL, E. E.; BROUSIUS, E. Reproducibility in the hematology laboratory: the microhematocrit determination. Am. J. clinic Path., v. 56, n. 1, p. 59-9, 1971.

HARARI， J.; FRANÇA, C. A. S.; CAMARGO, R. Climatology and hidrography of Santos Estuary. In: Neves, R.; Baretta, J.; Mateus, M. (Ed. ). Perspectives on integrated coastal zone management in South America. Lisboa: IST Press, 2008. p. 147-160.

HORTELLANI, M. A.; SARKIS, J. E. S.; BONETTI, J.; BONETTI, C. Evaluation of mercury contamination in sediments from Santos - São Vicente Estuarine System, São Paulo State, Brazil. J. Braz. Chem. Soc., v. 16, n. 6A, p. 1140-1149, 2005

KIRSCHBAUM, A. A.; SERIANI, R; PEREIRA, C. D. S.; ASSUNÇ̃̃O, A.; ABESSA D. M. S.; ROTUNDO, M M.; RANZANI-PAIVA, M. J. T. Cytogenotoxicity biomarkers in fat snook Centropomus parallelus from Cananéia and São Vicente estuaries, SP, Brazil. Genetics mol. Biol., v. 32, n. 1, p. 151-154, 2009.

LAMPARELLI, M. L.; COSTA, M. P.; PRÓSPERI, V.A.;BEVILÁCQUIA, J. E.; ARAÚJO, R. P. A.; EYSINK, G. G. L.; POMPÉIA, S. 2001. Sistema Estuarino de Santos e São Vicente, São Paulo. São Paulo: CETESB, 2001. 178 p. Relatório Técnico.

LEMLY, A. D. Metabolic stress during winter increases the toxicity of selenium to fish. Aquat. Toxicol., v. 27, p. 133-158, 1993.

MEDEIROS, P. M.; BÍCEGO, M. C. 2004. Investigation of natural and anthropogenic hydrocarbon inputs in sediments using geochemical markers. I. Santos, SPBrazil. Mar. Pollut. Bull., v. 49, p. 761-769, 2004.

NATT, M. P.; HERRICK, C. A. A new blood diluent for counting the erythrocytes and leucocytes of the chicken Poultry Sci., v. 31, p. 735-738, 1952.
NIKINMAA, M. Effects of adrenalinje on the red cell volume and concentration gradient of prótons across the red cell membrane in the raibow trout, Salmo gairdneri. Mol. Physiol., v. 2, p. 287-297, 1982.

NIKINMAA, M.; HUESTIS, W. H. Adrenergic swelling of nucleated erythrocytes: celular mechanism in a bird, domestic goose, and two teleosts, striped bass and raibow trout. J. expl Biol., v. 113, p. 215-224, 1984.

OLIVEIRA-RIBEIRO, C. A.; NETO, F. F.; MELA, M.; SILVA, P. H.; RANDI, M. A. F.; RABITTO, I.S.; ALVES COSTA, J. R. M.; PELLETIER, E. 2000. Hematological findings in neotropical fish Hoplias malabaricus exposed to subchronic and dietary doses of methylmercury, inorganic lead, and tributyltin chloride. Environ.Res, v. 101, p. 74-80, 2000.

PACHECO, M.; SANTOS, M. A. Biotransformation, genotoxic, and histopathological effects of environmental contaminants in European eel (Anguilla 2002. anguilla L.). Ecotoxicol. Environ. Saf., 53(3):331347.

Pereira, C.D.S; Abessa. D.M.S.; Bainy, A.C.D.; Zaroni, L.P.; GASPARRO, M. R.; BÍCEGO, M. C.; TANIGUCHI, S.; FURLEY, T. H.; SOUSA, E. C. P. M. Integrated Assessment of Multilevel Biomarker Responses and Chemical Analysis in Mussels From São Sebastião, São Paulo, Brazil. Environ. Toxicol. Chem., v. 26, n. 3, p. 462-469, 2007.

RANZANI-PAIVA, M. J. T. Características hematológicas da tainha, Mugil Platanus Günther, 1880 (Osteichthyes, Mugilidae) da Região Estuarino-Lagunar de CananéiaSP. Bolm Inst. Pesca, S Paulo, v. 22, n. 1, p. 1-22, 1995.

RANZANI PAIVA, M. J. T.; RODRIGUES, E. L.; EIRAS, A. C. ; VEIGA, M. L.; PACHECO, F. J. Alterações hematológicas em curimbatá Prochilodus scrofa, Steindachner, 1881, expostos ao Dipterex 500 (Trichlorfon). Bolm Inst. Pesca, S Paulo, v. 24 (esp.), p. 187-196, 1997.

RANZANI-PAIVA, M. J. T.; SILVA-SOUZA, A. Hematologia de peixes Brasileiros In: RANZANI-PAIVA, M. J. T.; TAKEMOTO, R. M.; LIZAMA, M. A. P. Sanidade de organismos aquáticos. São Paulo: Varela, 2004. p. 89-120.

RANZANI-PAIVA, M. J. T.; RODRIGUES, E. L.; VEIGA, M. L.; EIRAS, A. C.; CAMPOS, B. E. S. 2003. Differential leukocyte counts in "dourado", Salminus maxillosus Valenciennes, 1840, from the Mogi-Guaçu River, Pirassununga, SP. Braz. J. Biol., v. 63 , n. 3, p. 517-525, 2003

RAILO, E.; NIKINMAA, M.; SOIVO, A. 1985. Effects of sampling on blood parameters in the rainbow trout, Salmo gairdneri Richardson, J. Fish Biol., v. 26, p. 725732, 1985.

RAO, D.; BHASKAR, B.; RAO, K, S; PRASAD, Y. V. K. D. Haematological effects in fishes from complex polluted waters of Visakhapatna Harbour. Mar. environ. Res., v. 30, p. 217-231, 1990.

SERIANI, R.; PINNA, F. V.; SILVEIRA, F. L.; ROMANO, P.; ABESSA, D. M. S. Toxicidade de água e sedimentos e estrutura da comunidade bentônica do estuário do Rio Itanhaém, SP, Brasil resultados preliminares. O Mundo da Saúde, v. 30, p. 628-633, 2006. 
SERIANI, R.; ABESSA, D. M. S.; MAGINI, C.; PINNA, F. V.; SILVEIRA, F. L.; ROMANO, P. Using bioassays and benthic community to evaluate the sediment quality at the estuary of Itanhaém River, SP, Brazil. O Mundo da Saúde, v. 32, p. 294-301, 2008.

SHAH, S. L. Hematological parameters in tench Tinca tinca after short term exposure to lead. J. appl. Toxicol, v. 26, p. 223-228, 2006

SOUSA, E. C. P. M., ABESSA, D. M. S., GASPARRO, M. R., ZARONI, L. P.; RACHID, B. R. F. Ecotoxicological assessment of sediments from the Port of Santos and the disposal sites of dredged material. Braz. J. Oceanogr., v. 55, p. $75-81,2007$.

STEGEMAN, J. J.; BROWER, M.; DI GIULIO, R. T. FÖRLIN, L.; FOWLER, B. A.; SANDERS, B. M.; VAN VELD, P. A. Molecular responses to environmental contamination: Enzyme and protein systems as indicators of chemical exposure and effect. In: Biomarkers: Biochemical, physiological, and histological markers of anthropogenic stress. HUGGETT, R. J.; KIMERLE, R.A.; MEHRLE JR., P. P.; BERGMAN, H .L. (Ed.). Chelsea, MI: Lewis Publishers, 1992. p. 235-335.
TETENS, V.; CHRISTENSEN, N. J. Beta-adrnergic control of blood oxygen affinity in acutely hypoxia exposed rainbow trout. J. comp. Physiol. B, v. 57, p. 667-675, 1987.

WINTROBE, M. M. Variations on the size and haemoglobin content of erythrocytes in the blood of various vertebrates. Folia haematol., v. 51, p. 32-49, 1934.

ZAR, J. H. 1996. Biostatistical analysis. 3rd. ed. Upper Saddle River, NJ: Prentice-Hall, 1996. 662 p.

(Manuscript received 09 March 2009; revised 15 May 2009; accepted 01 August 2009) 